\title{
THE IMPORTANCE OF THE FIQH WORKS WRITTEN IN THE XII CENTURY IN MAVERANNAHR
}

\author{
Yusupova Nigora Jaloliddin Kizi \\ Ph.D. Tashkent Islamic University, \\ Assistant Professor of the Department \\ "National Idea, the Foundations of Spirituality and Law",
}

\begin{abstract}
The article is devoted to the study of the scientific activities of the great Hanafi faqih of the 12th century in Maverannahr, such as Burhaniddin Marginani, Iftikhoruddin Tohir al-Bukhari, Alouddin Samarkandi, Alouddin al-Kosoni. The article analyzes the structure, methods, chapters and themes of the famous works of these scientists, which are significant for today. The article also talks about the role of their works in Islamic law, and examines the universal values and ideas of philanthropy, especially the oriental moral education set out in the views of the scientists of Maverannahr relating to family relationships. Also, the article emphasizes and analyzes the importance and role of family rules in Islam, its peculiar properties, socio-economic, cultural and educational bases that are very effective in educating members of the family in the spirit of a national idea, values and patriotism.
\end{abstract}

Key words: Islamic law, Islamic lawyer, fetwa, source, kazi, adjudication, interpretation, family problems, matrimonial relationships, women rights, family code law, Qur'an and Hadiths.

The fundamental pillars of the state and law of Uzbekistan - the foundations of national statehood, being very ancient and powerful, have a centuries-old history.

The rich culture of our region, which has an ancient history, has been enriched and perfected over the centuries by the creativity of our great ancestors, who are conductors in the field of science, eventually rose to the 
highest stages of development, becoming the property not only of our country, but of all human civilization. The first President of Uzbekistan Islam Karimov on this occasion expressed the following idea: "The invaluable legacy of our ancestors formed the spiritual and psychological consciousness and way of life of many generations, even today it retains its influence." [1]

As Islam Karimov rightly states, "Since the emergence of Islam on earth for centuries, hundreds and thousands of scholars and religion servants many countries have been engaged in Islamic jurisprudence."[2] These include the faqihs of Maverannahr, whose greatest works and legal doctrines have made a huge contribution to the expansion of the branches of Islamic law and the all-round development of science fiqh.

The faqihs of Uzbekistan achieved universally respected scientific achievements on the way to improving Islamic jurisprudence, not only during the Tahrizh and Tarchish periods that followed the period of the Sultanah, but also during the Taklid period, along with the creation of new scientific branches and schools in the field of Kalyam and jurisprudence, gave the world new legal Theory and doctrine.

As is known, in the 12th century in Central Asia, including in the territory of Maverannahr, events began that affected the progress and improvement of the science of physics. One of these factors, A. Muminov believes, is that as a result of the creation of the Karakhanid state in this period, "ties with Khorasan were weakened in Maverannahr, which became the basis for strengthening and independent development of local legal schools. The strengthening of autonomies in the central cities led to the expansion of the scale of influence of the Muslim clergy. Thus, real conditions arose for the realization of the rules of fiqh in life. Bukhara and Samarkand have turned into true centers of scientific creativity. In these cities also worked the faqihs of such large cities as Nasaf, Merv, Fergana".[3]

According to the conclusions of the Turkic researchers, at this time almost 300 faqihs acted, more than 150 works of fiqh (Islamic law), 20 fatwas (collections of fatwas), 98\% of them refer to the current of Hanafites.

The introduction of a huge number of new information from the priceless works created during this period, into the traditional shell of the Hanafi fiqh, was carried out in three ways:

1) Comments were written on the works at the level of labor of 
Muhammad ibn Hasan al-Shaiboni "Zohir-ar-rivoi";

2) New independent books were prepared in the framework of the science of Fiqh;

3) The fatwa of the faqihs of the earlier era and contemporaries were combined into collections of fatwas.

As a generalizing of all these works of the textbook was created the work of Burhaniddin Marginoni "Kitob al-Hidoya fi sharh al-Bidoya". [4]

Valuable legal work of Marginoni "Al-Hidoya" is distinguished by its conciseness, perfection and in the aspect of comparative study of the Hanafi School in comparison with other schools of the Sunni type, has a peculiar great theoretical and practical significance.

Burhaniddin Marginoni was able to find many ways to solve innumerable legal issues within the broad framework of the Hanafi school.[5] In spite of the fact that he did not have the authority to directly and independently perform the Izhtihod, he widely used the method of kiyas (kiashi sting) in the creation of his scientific and legal works, especially the second type of kiyasah - "kiyashi hafi" or "istihson."[6] Therefore, some scholars recognized Marginoni as "al-Mujtahid phil-mazhab," or Mujtahid within the current (mazhab).[7]

According to Marginoni, knowledge comes from three sources. The first is the Nass, which includes the verses of the Qur'an and the hadith of the Prophet (SAV), which are sources of Sharia. The second is mind and thinking, the third is information that is formed in the organs of sense of badia, that is, without any mediation (directly by man).

The thinker in the work "Al-Hidoya" when covering the issues of fiqh uses the methods of kiyas and compares the doctrines of various currents. In the argument, he refers primarily to the Qur'an, then to the Sunnah, after which he proceeds to Izhma and Kiyasu. If kiyas can not help solve a problem, he goes on to the method of istehson (kiyashi hafiy). In the absence of a decision, he issues a conclusion on the basis of customs (urf).

Burhaniddin Marginoni, in resolving problems, pays special attention to kiyas as a source of mental analysis, and also relies on sources such as istehson and urf, which opens up enormous opportunities for effective resolution of legal problems. He assesses legal issues concerning the practical life of people, not only through prayer rituals, but also by analyzing other 
evidence, applying the above criteria. He also uses the method of logical analysis, extensively uses methods of piercing (deduction) and scientific analysis. He studies each problem from the standpoint of a comparative analysis of the currents, draws his conclusions and, choosing, in his opinion, the most preferable opinion, gives him priority. For this reason, we can say that Al-Hidoya, in fact, is a philosophical analysis of Islamic law.[8]

"Al-Hidoya" - this is the crown work of Marginoni, recognized also by the outstanding faqihs, contemporaries of Burhaniddin Marginoni. Thus, scholar al-Haddod noted that: "Hidoya, along with the Quran, discredited the Sharia books written before her [9]".

The work "Hidoya" was written for quite a long time, almost 13 years. The reasons for this are as follows. First, as the basis of "Bidoyatil-Mubtadi", the works of Imam Muhammad al-Shaibony "Al-Jomi al-Sagir" and al-Kuduri "Mukhtasar" were taken, where there were thousands of questions that had some relation to the legal issues given in Work "Bidoyatul-mubtadiy". Among them there were problems connected with the practical life of the people, who had not yet found their solution. From this point of view, the study of the changing nature of that time, the identification of priority problems from the problems of a lesser property, the determination of ways to solve them, required the author of great intelligence, attention, in-depth analysis and in-depth observations.

Secondly, because Burkhaniddin Marginoni lived in the fifth era of the Muharrija (an era when scientists sought ways to solve new and complex legal problems within the current framework by referring to the works of the men who lived in former times the Sultan and great scholars of jurisprudence) from six epochs of science Fiqh (the era of the Prophet, Sahoba, Tobin, Mujtahid, Muharrija and Mukallid (imitators), so he did not have the authority to directly perform the Ijtihod (interpretation), which is due to the fact that at the beginning of the 4th century $\mathrm{AH}$ (the 10th century $\mathrm{AD})$ There was an idea that No one has the right to give an independent claim in Islamic law. All activities in the field of jurisprudence should be carried out within the framework of the interpretation (tafsir) of the basic legislative rules determined by great scientists.[10] However, Muhammad Abdulhay Laknawi in his famous work "Al-Fawoyd al- Bahia" divides the scientists of the Hanafi into six categories, while placing Burhaniddin 
Marginoni and al-Quduri in a number of scientists who have the potential to give certain stories "askhabut-tarjiyh"(priority among the others).

In such conditions Burhaniddin Marginoni was presented with numerous fatwas (legal collections) written by different authors. They were given thousands of questions, dozens of conclusions, conclusions on specific problems, doctrines that often even contradicted each other. The author was to refer to the main sources of the Shariah, then to the works of the scholars of Abu Hanifah, Imam Molik, Imam Shofi, Imam Ahmad ibn Hanbal, the books of Al-Shayboni "Zohirur-Rivoya", the works of Abu Yusuf "Kitobul-hiroj", "Adabul-Goat", "Contradictions between Abu Hanifah and Ibn Abilailo", "Recalling the opinions of Avzoi and Anas ibn Molik on some legal issues", works by Imam Zufar, and also to read countless books and Collections on specific areas of Islamic law, compare the where ideas and opinions, will eventually make its reasoned findings and conclusions. [11]

Naturally, the choice of the most vital and necessary tales, the justification of their fidelity with the help of wise aphoristic evidence, the strengthening by means of reasonable arguments, the deep entry into the text and the content of selected works, the definition of their legal foundations, required very great work and a systematic approach.

Another feature of "Hidoya" is that it provides for extensive application of rules based on "Ilmul-hulof" (comparative law). This was facilitated by the fact that Burhaniddin Marginoni was a recognized scholar and specialist in the field of legal science. Burhaniddin Marginoni in the work of Hidoya in the process of resolving legal problems takes into account not only the three main trends (the currents of hanafia, molykia, shafiya), but sometimes (to the place) opinions, ideas about the Zohiri and Avzoi sense, expresses his opinion on each of the studied Opinions, views. From this position, "Hidoya" is considered a very important and significant source for studying the school "Ilmul Hilof" in a wide framework. The reason that the relevant questions of the Hanbali current were not included in the Hidoya and other works of the leading faqihs is that the sunkahs of the Sunnah, even before the end of the 12th century, recognized the hanbalits not as fakihs, but as muhaddis.

Thus, the book Al-Hidoya, written by Burhaniddin Marginoni, including four volumes, as the most important and perfect legal Sunnite text, 
the Hanafi current, consists of more than 55 books, hundreds of chapters and sections, covers virtually all branches of Islamic law, for Exclusion of inheritance law. The reason that Burhaniddin Marginoni did not include hereditary law in his book is that Imam Azam Abu Hanifa singled out the problem of inheritance as a separate science from the teachings of fiqh, giving it the name "al-Faroiz."

The first volume of "Hidoya" is dedicated to the issues of takhorat and the practice of worship (namoz, ruza, zakat and hajj), the second volume deals with family law issues, slave maintenance problems, punishments hudud (defined by Allah), customs of international law, cooperation, Law, the third volume - the issues of civil turnover (civil law), the court, the trial process, the fourth volume - the problems of agriculture and land law, types of crimes, witnesses,

Another outstanding scholar of the Hanafi trend, who in the twelfth century wrote and wrote a large number of works in the fiqh industry, known for his priceless fatwas, is the thinker of Iftikhooruddin Tohir ibn Ahmad Bukhari. [12] Works - the fatwas of Iftikhoruddin Tohir ibn Ahmad Bukhari are considered to be one of the most valuable and significant sources of the Hanafi current ever written in the territory of Maverannahr. Despite the fact that Iftikhoruddin Tohir ibn Ahmad Bukhari lived all his life in Bukhara, Margelan and Sarakhs, his works were recognized in many countries of the Muslim world. Also, the works of the scientist differ in that they are created on the basis of local conditions and customs inherent in the region.

Sources report three famous works of the scientist: "Kitob an-nisob", "Khizanat al-vokeot" and "Khulosat al-Fatwo". Ismoil Pasha Bagdadi also speaks of such a work of the scientist as "Khizanat al-fatwo". [13]

Khoji Khalifa to his work "Kashf az-zunun" testifies that: "Khizanat alfatwo" is the work of Iftikhooruddin Tohir ibn Ahmad al-Bukhari al-Sarahsi and is written within the framework of Al-Hanafiyah. This scientist has the gift of "Khulosa". The book "Khizanat al-fatwo" is a very revered work, there are very few copies left. "[14]

Iftikhoruddin Tohir al-Bukhari himself did not say anything about the work "Khizanat al-fatwo". He indicated only the works of "Kitob an-nisob", 
"Khizanat al-vokeot" and "Khulosat al-fatwo." [15] Therefore, the presence of such a work of a scientist as "Khizanat al-fatwo", is not yet clear.

The work of Iftikhoruddin Tohir al-Bukhari "Khulosat al-Fatwo" is considered to be a shortened work of the books of the scientist "Kitob an-nisob" and "Khizanat al-vokeot".

The Thinker uses his own specific style when writing a book. He divides his work into books, books into chapters, in addition, he applies the term parts, which has never been used before, and divides chapters into parts and chunks into skills. Each book introduces in detail the questions to be covered, how many chapters are in the book, what issues are discussed in each chapter, what issues are addressed in each chapters chapter, etc.

The order of writing the chapters of the book differs from the generally accepted books of the fiqh of Hanafi. They begin with the book "Takhorat Kitob" and end with the book "Shuf'a (The Right of Privileged Acquisition) of the Whale."

In the generally accepted books of the fiqh of Hanafi, the order begins with the book "Takhorat of the Whale," ending with the book "The Phantom of the Whale."

In the work "Khulosat al-fatu", opinions, decisions, fatwa of the learned theologians of Iraq, Balkh, Bukhara, Samarkand, Margelan, Sarahs and some other cities are prepared, taking into account the local conditions and customs inherent in the region.

The work "Khulosat al-fatwo" by Iftikhoruddin Tohir Bukhari is an important source in the history of Islamic jurisprudence, its significance in the scientific, doctrinal and practical progress of the Hanafi doctrine testifies that it can be recognized as a huge achievement of jurisprudence not only in Central Asia, Peace. Since, this work served as a source for works of fiqh of Hanafi, created in subsequent periods.

This work of the scientist is the largest and most reliable source written in the chapter "Fatwa". The work was used in the practical activities of the fuqaha, kaziev, muftis as an important source, from the period of the author's life to the first quarter of the last century. In the libraries of that era there were copies of this work, interested in the issues of many branches of law, found answers from this work. In cases where 
there were disputes about a particular issue, if the Fukiyas said that there was a specific answer in the "Khulosa", no fakie objected to it, and this decision was unanimously adopted. Therefore, the work is still attractive to researchers conducting research in many areas of Islamic law.

The work of the author "Khulosat al-Fatwo" has come down to our days, now ancient copies of this work, relating to different centuries, are stored in the libraries of Muslim countries and our country. In the Fund of Manuscripts of the Academy of Sciences of the Republic of Uzbekistan under Inv. No. 8868, 6505, 8427 and others there are altogether eighteen Arabic manuscripts of the work. Some of them consist of one volume, some of two volumes, with both volumes included in one book.

Iftikhoruddin Tohir Bukhari is a third-generation clergyman who has the right to carry out the interpretation of the issue without any permission from the founders and associates of the current. When we speak of muzhtahidah flow Hanafi, mentioned the following: "No scientist can not oppose such jurists as al-Hassof, al-Tahawi, al-Karkhi, Shams alaimma al-Halvoni, Shams al-aimma al-Sarakhs Fahrul-Islom Bazdavi, Burhaniddin Mahmud Ibn al-Sadr Sohib "az-Zahir" and Sheikh Tohir ibn Ahmad Sohib "Hulosat al-fatwa," Fakhriddin Kozihon, Ibn Humom in matters of usul and issues Furuya. Because they are scientists who can make decisions, based on the usul and koid methods, on non-prohibited (nass) questions [16]. "

Faqih Ibn Obidin, to express their opinion on scientific degree Iftihoruddina Tohir Bukhari, emphasizes the author of "Hulosa" - is one of the greatest scientists, credible. Therefore, following his words, the examples given is mandatory (vozhyb). The confidence of the faithful in the words of Iftikhooruddin Tohir Bukhari increased to such an extent that they began to follow his opinion in the affairs of fiqh. "[17]

Other great representatives of the school of fiqh Mavara were Alouddin Muhammad ibn Ahmad Samarkand (1145) and Alouddin alKosoni (1191).

Alouddin Muhammad ibn Ahmad Samarkandi studied the science of fiqh from such prominent figures Abul Ma'in Makhuli and Sadrul-Islom Abul-Yusr Bazdavi and became a recognized scientist of his era, who have made a significant contribution to the jurisprudence of the Hanafi 
persuasion. The book "Tukhfatul-fukaho" written by him in the framework of the school of fiqh Hanafi deserves great attention, many comments have been prepared on this book. Alouddin Samarkandi besides science of fiqh as well as prominent figures of science Kalyam Hanafi, he was a follower and promoter of the teachings of Imam Abu Mansur Moturidi.

As written in the sources, he had a daughter, Fatima [18], which is a prominent scientist, having the right to give fatwa, worked closely with his father in the field of fiqh.

The time when accommodated Alouddin as-Samarkandi and its daughter Fatima Bin Muhammad, accounted for 2 half-century XI and XII one-half century. During this period in the territory of Maverannahr the contradictions among representatives of various Muslim currents sharply increased, in particular between Hanafi and Shafi'i.

The first information about Alouddine as-Samarkandi and his daughter Fatima Bin Muhammad, come down to us, found mainly in the works of students as-Samarkandi - introduction to the book Alouddina al-Kosoni "Bado", as well as book as-Samoni (1167) "Kitob al-ansob".

Fotima Bin Muhammad as-Samarkandi (up to 1191) from an early age studied with his father in the disciplines kiroat, arabic, fikx. Studying with her father, she reached the greatest heights in the science of fiqh, becoming the most famous scientist. "This woman had in the science of fiqh such knowledge and skills, - the sources - that fatwas her father also began to put her signature and seal" [19]. She knew by heart the well-known work of her father "Tukhfatul fukaho." Unfortunately, from the sources that have reached us it is not known a single work of this outstanding woman - a scientist.

Husband Fotima Bin Muhammad - one of the most famous jurists era Qarakhanid Al-Kosoni - Alouddin Abu Bakr Ibn Masud ibn Ahmad, it is derived from the big city Koson, "located in the north of the river Sayhun (Syrdaya) - near Fergana (Shosh)" [20].

Pupil and son-in-Alouddina Muhammad, a prominent jurist era Karakhanids Imam Abu Bakr ibn Masud al-Kosoni wrote a three-volume commentary "Badoius-sanoi, fi tartibish-sharoi" to work his teacher "Tuhfatulfuqaha '(jurists Dar). [21] 
This famous work Al-Kosoni was published in 1327-1328 in Cairo (I-VII volumes). Respected not only in the Islamic world, but also among Western scholars, the work of fiqh, has not lost its value even today.

As can be seen from our analysis, during Hanafi is widely spread on the territory of the Maurya, while a large number of large and prominent representatives of the Imams and the current, reached perfection, both in religion and in jurisprudence. Based on work Abu Hanifa, and the books of his talented pupils Muhammad ibn Hasan Shayboni, Abu Yusuf "Zohirur-Rivoya", "Kitobul-hirozh" that make up the legal and ideological foundations of the Hanafi doctrine, created a very significant legal proceedings, who have made a huge contribution to the development and prosperity Currents of Hanafi. For example, eight prominent scientists of the faqihs Maverannahr wrote works in the science of fiqh under the name "al-Mabsut." Of those work Fahrul Islom AlBazdavi Mabsut consisted of 11 volumes, the works of Sheikh ul-Islam Muhammad ibn Husayn al-Bukhari al-Hanafi Mabsut, Shamsul-aimma alSarakhsi Mabsut includes 15 volumes. These works, covering almost all areas of Islamic law, including marriage and family, crime, property relations, international law, recognized as an invaluable heritage of Islamic culture.

At the present stage of development of our society, in the process of improvement of the Uzbek people of spirituality, in particular, religious literacy becomes a social need scientific analysis of the provisions of the Islamic teachings concerning family relations. Therefore, the study of social norms regarding the nature of family relations in Islam, the scientific analysis is absolutely incorrect beliefs about family relationships fundamentalist movements, rooting more and more today, as well as their negative social consequences aspect is extremely important from a practical position.

Under the rule of the totalitarian regime, the concepts of family relationships as equity, debt, commitment, relationships between spouses, parents and children, family members, as defined in the verses of the Koran and the Hadith, the basic requirements arising from the universal moral values, have been completely perverted.

In this context, the study of the problem recognized is very important to analyze the real primary sources of Islamic law, the classical fiqh books, including the works of scientists - natives of Central Asia, for example, was written in the XII century books Fakhruddin Kozihon "Fatwo Kozihon", Burkhaniddin Marginoni 
"Al-Hidoya", Alouddin as-Samarkandi "Tuhfat ul-fuqaha, Iftihoruddin Tohur Bukhari "Hulosat ul-fatwa", Aboul Cosim as-Samarkandi "al-fiqh al-Nafi" Because Islamic law on temporary stage is recognized as one of the types of customary law, is well-known degree of depth of its impact on people's lives. At the present stage of development of our society, in the process of improvement of the Uzbek people of spirituality, in particular, religious literacy becomes a social need scientific analysis of the provisions of the Islamic teachings concerning family relations. Therefore, the study of social norms regarding the nature of family relations in Islam, the scientific analysis is absolutely incorrect beliefs about family relationships fundamentalist movements, rooting more and more today, as well as their negative social consequences aspect is extremely important from a practical position.

The laws of Sharia - fiqh, has been essential in the legal regulation of public relations of the peoples Maverannahr for over a thousand years, the rules relating to the registration of marriage and divorce, the legal relationship between spouses, parents and children, guardians and caregivers, taken into care (custody) By persons, as well as by the obligations and guarantees of their execution, have been settled comprehensively and in a very perfect manner. Faqihs in their writings sought to bring certain rules of law in line with local conditions.

When studying the issue of family relations in the writings of the scientists of Maverannahr, one should approach from the socio-legal position. Since, at the time of our scientists in their works we have tried to highlight the social and legal status of the family in Islamic law; The basis for the formation and strengthening of family relations.

In conclusion, it should be noted that the study of the heritage of our great scientists and thinkers, to fully develop in the XII century, Islamic sciences and left behind a priceless works, it is a key challenge facing the researchers. Since the legacy of scholars such as Burhaniddin Marginoni, Iftihoruddin Tohir Bukhari, Fakhruddin Kozihon, Alouddin Samarkandi Alouddin Kosoni and many others, it is considered an important source in the history of Islamic law, and their place in the scientific, theoretical and practical development of the Hanafi doctrine, it became a significant achievement Not only for the peoples of Central Asia, but also for the law in the entire Muslim world. This is due to the fact that established in this era of 
scientific heritage has served as a source for works of Hanafi fiqh, written later, was even an important source in the practice of jurists, qadis, couplings up to the first quarter of the last century. Moreover, the provisions of these works, based on the findings of current Hanafi, relatively soft and comfortable for use, taking into account local traditions, like the laws of this current, widely used in most of the Muslim states, respectively Qadi (judge), when dealing with controversial cases arising different Public relations (civil, marriage-family), along with other sources have successfully used these sources.

So, in Maverannahr, the science of this current has been further developed by the actions of the Hanafi currents analyzed by us. Another important aspect of that time is that not one direction of the Islamic religion developed, but many other related sciences. Therefore, the works created at that time attract researchers who conduct scientific research in Islamic law at the present stage. For, the definition of new information about the life of our great faqihs, the study of their influence on the socio-political picture of Maveranahr of that time, the study of some aspects of their works that remain relevant and still relevant can prove to be very useful. 


\section{References}

1. Karimov I. Uzbekistan: national independence, economy, politics, ideology. - T.: “Uzbekistan”, 1996. - P. 40-41.

2. People's word, October 15, 2000.

3. Muminov A. "Muslims of Maveranakhra: xanafity". // Oriental Studies, No. 9/1999. - P. 42.

4. Muminov A. "Muslims of Maveranakhra: the Hanafites" // Oriental Studies, No. 9/1999. - P. 42.

5. The flow of Hanafi differs from other currents in that, in comparison with them, along with the main three sources of Sharia law (Qur'an, Sunnah, Izhma), the fourth rational (intellectual) source, that is, kiyas, is given sufficient weight. In addition, in the course of Hanafiah, the customary law of local peoples is widely used as an additional source of law.

6. The word "Istehson" from Arabic means approval of priority, the choice is most preferable in comparison with another. In the science of fiqh, the term itehson means the transfer of the husband-devil from the direct kiyas to the secret, hidden kiyas, in other words, it is the decision to choose the most preferable, advantageous in the interests of Muslim society, on the basis of expediency, as an exception, to abandon the generally accepted rule in favor of the most Beneficial solution for Muslims. For more details see: Toshqulov J., Yusupova N., Bekmirzaev I., Sarsenboev O., Masaidov S. Islamic jurisprudence. Tutorial. - T.: Ed. Tashkent Islamic University, 2014. P. 90.

7. Yusupova N., Zhuzzhoniy A.Sh. Burhaniddin Marginoni: Life and scientific heritage. - T.: "Academy", 2007. - P. 17.

8. Yusupova N.Zh., Zhuzzhoniy A.Sh. Burhaniddin Marginoni: Life and scientific heritage. - T.: "Academy", 2007. - P. 18.

9. Muhammad Abdulhay. The manual as an introduction to Hidoy. Laknau: 1394 h. </s>. - P. 3.

10. Majid Haddoury, Herbert Lebisni. "Right in Islam," Tehran-New York, 1958. - P. 105.

11. Yusupova N.Zh., Zhuzzhoniy A.Sh. Burhaniddin Marginoni: Life and scientific heritage. - T.: "Academy", 2007. - P. 22. 
12. The sources indicate that Iftikhoruddin Bukhari was born in 482/1090 in Bukhara, died in 542/1147 in the month zhumadul-avval in the town of Sarakhs. See: Kurashi Abu Muhammad Abdulkodir ibn Abilvafo Muhammad ibn Muhammad al-Misri. Al-Jawohir al-muziyah fi Tabaqot alHanafiyyah (hereinafter: Al-Qurashi, Al-Jawohir). 5 volumes, under the general editorship of Abdulfattoh Muhammad al-Hulva. Cairo: "Khijr", 1993. I t. - S. 188; Laknawi Muhammad Abdulhay al-Hindi. Al-Fawoid al-Bahiyya fi Tarojum al-Hanafiyyah (hereinafter: Abdulhay Laknawi, Al-Fawwoid). Beirut: "Daral-kutub al-Islamiyah." 1998. - P. 146.

13. Ismoil Pasha al-Baghdadi. Hadiyatul-orifin li-asmyl muallifin wa osarul-musannifin. - Istanbul: 1951. 1 t. - S. 430.

14. Mustafo ibn Abdullah ar-Rumiy al-Hanafiy al-Shahir bi-Khoji Khalifa. Kashf az-zunun an asmo al-kutub va-l-fonun. Beirut: "Dor al-kutub al-ilmiyyah", 1992. 1 vols - P. 204.

15. Iftikhoruddin Tohir ibn Abdurrashid al-Bukhari. "Hulosat alFatwo". Turkey. Library of the Mufti of Istanbul. Department of Fiqh // Manuscript. Inventory No .: 140.1077 g. - P. 7.

16. Al-Qurashy. Al-Jawohir. I f. - P. 558; Muhammad Amin al-E'son al-Mujaddidiy al-Barkatiy al-Hanafiy. Qawaid al-fiqh. - Karachi. 1407. I f. - P. 568.

17. Sayyid Muhammad Amin Obidin ibn Sayyid Umar Obidin ibn Abdulaziz ad-Damashki al-Hanafi. Hoshitu Roddul-Mukhtor Alad-DurrilMuhtor Sharh Tanvirul-Absor. 2-edition. "Dor al-fikr", 1386, VI vol. - P. 38.

18. Yusupova N. The great scientist from Samarkand. // - T: Khidoyat -2011. №1. - P. 28.

19. Qurashi Abu Muhammad Abdulkodir ibn Abilvafo Muhammad ibn Muhammad al-Misri. Al-Jawohir al-muziyah fi tabaqot al-Hanafiyya. Heydarabad, 1913. II volume - P. 278-279; Toshkuprizoda Ahmad ibn Mustafa. Miftakh as-saoda va meesbah as-siyoda. II vol. Heydarabad, 1905. P. 136-137; Laknawi Muhammad Abdulhay al-Hindi. Al-Fawoid al-bahiyya fi Tarojum al-Hanafiyyah. Cairo, 1906. - P. 158.

20. Toshkuprizoda. - P. 135; Laknawi Muhammad Abdulhay alHindi. Al-Fawoid al-bahiyya fi Tarojum al-Hanafiyyah. Cairo, 1906. - P. 53; Qurashi Abu Muhammad Abdulqodir ibn Abulvafo Muhammad ibn 
Muhammad al-Misri. Al-javohir al-muziyah fi tabaqot al-khanafiyya. Heydarabad, 1913. II vol. - P. 244.

21. Mustafo ibn Abdullah ar-Rumiy al-Hanafiy ash-shahir bihoji Khalifa. Kashf az-zunun an asmo al-kutub va-l-fonun. Istanbul. Al-Olam. - P. 294. 